\title{
Abundance of ruminal bacteria, epithelial gene expression, and systemic biomarkers of metabolism and inflammation are altered during the peripartal period in dairy cows
}

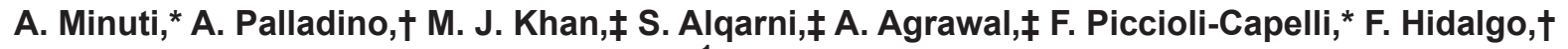 \\ F. C. Cardoso, $\ddagger$ E. Trevisi, ${ }^{*}$ and J. J. Loor ${ }^{1}$ \\ *Istituto di Zootecnica, Facoltà di Scienze Agrarie, Alimentari e Ambientali, Università Cattolica del Sacro Cuore, Piacenza, 29122, Italy \\ †Department of Animal Production, Faculty of Agriculture, University of Buenos Aires, Av. San Martin 4454, 1417 Ciudad de Buenos Aires, \\ Argentina \\ ‡Department of Animal Sciences and Division of Nutritional Sciences, University of Illinois, Urbana 61801
}

\section{ABSTRACT}

Seven multiparous Holstein cows with a ruminal fistula were used to investigate the changes in rumen microbiota, gene expression of the ruminal epithelium, and blood biomarkers of metabolism and inflammation during the transition period. Samples of ruminal digesta, biopsies of ruminal epithelium, and blood were obtained during -14 through $28 \mathrm{~d}$ in milk (DIM). A total of 35 genes associated with metabolism, transport, inflammation, and signaling were evaluated by quantitative reverse transcription-PCR. Among metabolic-related genes, expression of HMGCS2 increased gradually from -14 to a peak at 28 DIM, underscoring its central role in epithelial ketogenesis. The decrease of glucose and the increase of nonesterified fatty acids and $\beta$-hydroxybutyrate in the blood after calving confirmed the state of negative energy balance. Similarly, increases in bilirubin and decreases in albumin concentrations after calving were indicative of alterations in liver function and inflammation. Despite those systemic signs, lower postpartal expression of TLR2, TLR 4, CD 45, and NFKB1 indicated the absence of inflammation within the epithelium. Alternatively, these could reflect an adaptation to react against inducers of the immune system arising in the rumen (e.g., bacterial endotoxins). The downregulation of $R X R A, I N S R$, and RPS6KB1 between -14 and 10 DIM indicated a possible increase in insulin resistance. However, the upregulation of IRS1 during the same time frame could serve to restore sensitivity to insulin of the epithelium as a way to preserve its proliferative capacity. The upregulation of $T G F B 1$ from -14 and 10 DIM coupled with upregulation of both $E G F R$ and $E R E G$ from 10 to 28 DIM indicated the existence of 2 waves of epithelial proliferation. However, the downregulation of TGFBR 1

Received April 17, 2015.

Accepted July 27, 2015.

${ }^{1}$ Corresponding author: jloor@illinois.edu from -14 through 28 DIM indicated some degree of cell proliferation arrest. The downregulation of $O C L N$ and TJP1 from -14 to 10 DIM indicated a loss of tightjunction integrity. The gradual upregulation of membrane transporters $M C T 1$ and $U T B$ to peak levels at 28 DIM reflected the higher intake and fermentability of the lactation diet. In addition, those changes in the diet after calving resulted in an increase of butyrate and a decrease of ruminal $\mathrm{pH}$ and acetate, which partly explain the increase of Anaerovibrio lipolytica, Prevotella bryantii, and Megasphaera elsdenii and the decrease of fibrolytic bacteria (Fibrobacter succinogenes, Butyrivibrio proteoclasticus). Overall, these multitier changes revealed important features associated with the transition into lactation. Alterations in ruminal epithelium gene expression could be driven by nutrient intakeinduced changes in microbes; microbial metabolism; and the systemic metabolic, hormonal, and immune changes. Understanding causes and mechanisms driving the interaction among ruminal bacteria and host immunometabolic responses merits further study.

Key words: gene expression, microbiome, transition cow

\section{INTRODUCTION}

The rumen microbial ecosystem is complex and essential for rapid degradation of feedstuffs and production of VFA and microbial protein for use by the cow. Several factors, including nutritional management, can induce modifications of the microbial population (Hernandez-Sanabria et al., 2012). Previous experiments detected changes in microbial populations around parturition, presumably a response to the change in diet from pre- to postpartum (Wang et al., 2012; Pitta et al., 2014; Lima et al., 2015). However, some evidence shows that the core ruminal microbiome is very stable even when cows are switched from a high-forage to a high-concentrate diet (Petri et al., 2013). 
Changes in microbial populations and animal metabolism may affect ruminal epithelial adaptations and nutrient absorption during the transition from late pregnancy to lactation. For instance, inducing SARA by feeding high-concentrate diets or alfalfa pellets resulted in similar decreases in $\mathrm{pH}$ and LPS endotoxin concentrations, but treatments induced different inflammatory responses, being more pronounced for graininduced SARA (Khafipour et al., 2009). Bannink et al. (2012) concluded that to maintain normal function, the ruminal epithelia in the peripartal cow respond in a coordinated manner to rapid dietary changes. However, the mechanisms underlying these adaptations are not fully understood.

The enlargement of ruminal absorptive area as a function of dietary increment of concentrate is well established (Bannink et al., 2012). However, evidence also points at mRNA expression and transporter and enzyme activity in the initial response driving epithelial cell function (Penner et al., 2011). Few studies have investigated the molecular adaptations of ruminal epithelium during the peripartum period (Dionissopoulos et al., 2014; Steele et al., 2015). These studies revealed the existence of interactions among genes of the immune system and those involved in the preparation for the onset of lactation (Dionissopoulos et al., 2014), as well as the presence of growth factors that seem to be regulated after parturition (Steele et al., 2015).

The main objective of this study was to evaluate the adaptations in major microbial species and ruminal epithelium expression of key genes associated with metabolism and tissue development, permeability, transport, inflammation, and immunity. Furthermore, ruminal VFA profiles and systemic biomarkers of energy metabolism, inflammation, and oxidative stress in blood were evaluated to enhance the systems understanding that the cow undergoes around parturition.

\section{MATERIALS AND METHODS}

\section{Animal and Experimental Design}

All procedures were performed under protocols approved by the University of Illinois Institutional Animal Care and Use Committee (protocol \#12094). Briefly, 7 rumen fistulated Holstein cows in their second or greater lactation were selected for this study. Cows were managed during the dry period using the 2-stage approach with a high-straw, lower-energy diet fed from dry-off through $-21 \mathrm{~d}$ from parturition followed by a lower-straw, higher-energy diet until parturition. The details of diet composition are reported in Supplementary Table S1 (http://dx.doi.org/10.3168/jds.20159722). At calving, cows were fed a common lactation diet until d 30 postpartum. Diets were fed as a TMR once daily $(0600 \mathrm{~h})$ using an individual gate feeding system (American Calan, Northwood, NH) during the dry period or in open individual mangers during lactation. Collection of BW, BCS, and milk production data and sampling for milk composition analysis were as described previously (Graugnard et al., 2012, 2013). Briefly, cow BW and BCS were obtained weekly throughout the study. Cows were milked 3 times daily after parturition, and milk was sampled thrice weekly for analysis of chemical composition.

Details of sampling methodologies and analytical procedures can be found in the Supplementary Materials (http://dx.doi.org/10.3168/jds.2015-9722). The sampling schedule during the experimental period is summarized in Figure 1. Briefly, blood was sampled from the coccygeal vein on $\mathrm{d}-14,-7,10,20$, and 28 relative to parturition and before the morning feeding using a 20-gauge BD Vacutainer needle (Becton Dickinson, Franklin Lakes, NJ) into Vacutainers $(10 \mathrm{~mL}$, BD Vacutainer, Becton Dickinson) containing lithium heparin. The plasma obtained after centrifugation was used to asses (1) inflammatory response markers: positive acute-phase proteins (haptoglobin, ceruloplasmin) and negative acute-phase proteins (albumin, paraoxonase); (2) liver function biomarkers: total bilirubin, aspartate amino-transferase, $\gamma$-glutamyl transferase; (3) energy and protein metabolism: glucose, cholesterol, NEFA, BHBA, urea, and creatinine; (4) minerals: $\mathrm{Ca}, \mathrm{Mg}$, and $\mathrm{Zn}$; (5) other parameters: total proteins, globulins, myeloperoxidase, ferric reducing antioxidant power, and alkaline phosphatase. Methods used for the determination of these parameters are described in the Supplementary Materials (http://dx.doi.org/10.3168/ jds.2015-9722).

After blood collection, grab samples of ruminal contents were harvested via the ruminal cannula from the ventral sac of the rumen. Ruminal fluid $\mathrm{pH}$ was determined immediately with a glass electrode, then the samples were stored at $-20^{\circ} \mathrm{C}$ and used for DNA extraction and VFA composition. Details of storage protocols and analytical procedures are presented in the Supplementary Materials (http://dx.doi.org/10.3168/ jds.2015-9722). At -14, 10, and 28 DIM ruminal papillae were biopsied from the ventral sac of the rumen. The excised ruminal papillae (approximately $500 \mathrm{mg}$ ) were immediately washed with sterile $0.01 M$ PBS (pH 6.8). The papillae were scraped to remove attached feed particles and rinsed 3 times to remove the nonadherent bacteria. The cleaned tissues were then frozen and stored in liquid nitrogen until RNA extraction. Details about tissue gene expression analyses are described in the Supplementary Materials (http://dx.doi. org/10.3168/jds.2015-9722). 
Table 1. Body weight, BCS, and milk yield and composition during the transition period in multiparous Holstein cows

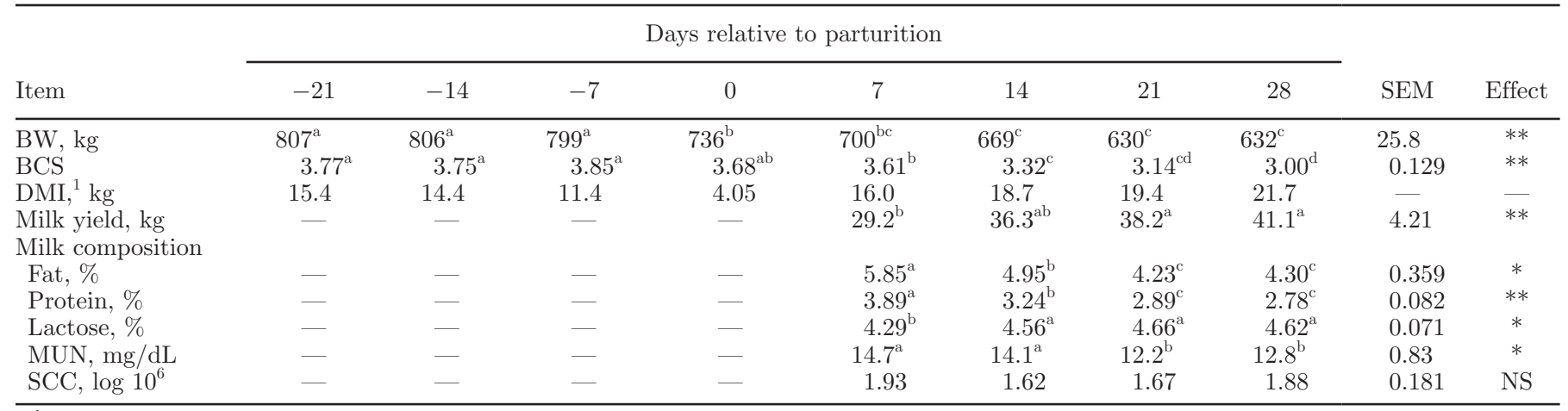

\footnotetext{
${ }^{\mathrm{a}-\mathrm{d}}$ Means with different superscripts are significantly different between days relative to parturition $(P<0.05)$.

${ }^{1}$ Estimated by using NRC equations (NRC, 2001).

${ }^{*} P<0.05 ;{ }^{* *} P<0.01 ; \mathrm{NS}=$ not significant $(P>0.10)$.
}

\section{Statistical Analysis}

The MIXED procedure of SAS (SAS Institute Inc., Cary, NC) was used for repeated measures analysis of milk production, BW, BCS, milk composition, microbial abundance, and gene expression. The fixed effect in the model was time (day or week), and the random effect was cow. Several covariance structures were tested, and selection was done based on the Bayesian information criterion. All means among time points were compared using the PDIFF statement of SAS (SAS Institute Inc., Cary, NC). Significant differences were declared at $P<$ 0.05 , and trends were declared at $P<0.10$.

\section{RESULTS}

\section{BW, BCS, Milk Yield, and Milk Composition}

The effect of time on cow performance is reported in Table 1. As expected, BW and BCS decreased during the experimental period $(P<0.01)$. Body weight began to decrease at calving and remained similar after the first week postpartum $(P<0.01)$. However, BCS continued declining after the first week postpartum $(P<$ 0.01 ), indicating that animals remained under negative energy balance until 28 DIM. Milk yield increased during the first $2 \mathrm{wk}$, and MUN, milk fat $(P<0.05)$, and protein $(P<0.01)$ decreased during the same period. Somatic cell count did not change $(P>0.05)$ during the experimental period.

\section{Ruminal Fermentation Variables}

The rumen fermentation data are reported in Table 2. Ruminal $\mathrm{pH}$ was higher $(P<0.05)$ before parturition in comparison with the postpartum period. However, ruminal $\mathrm{pH}$ was higher $(P<0.05)$ at 28 DIM (Table 2 ). Despite this, major VFA (acetate, propionate, and butyrate) had a pattern similar to the decrease in ruminal $\mathrm{pH}$. Acetate (as a proportion of the total VFA) decreased slightly after parturition $(P<0.05)$, and propionate and caproate tended $(P<0.10)$ to increase after parturition. The acetate:propionate ratio also tended $(P<0.10)$ to decrease after parturition.

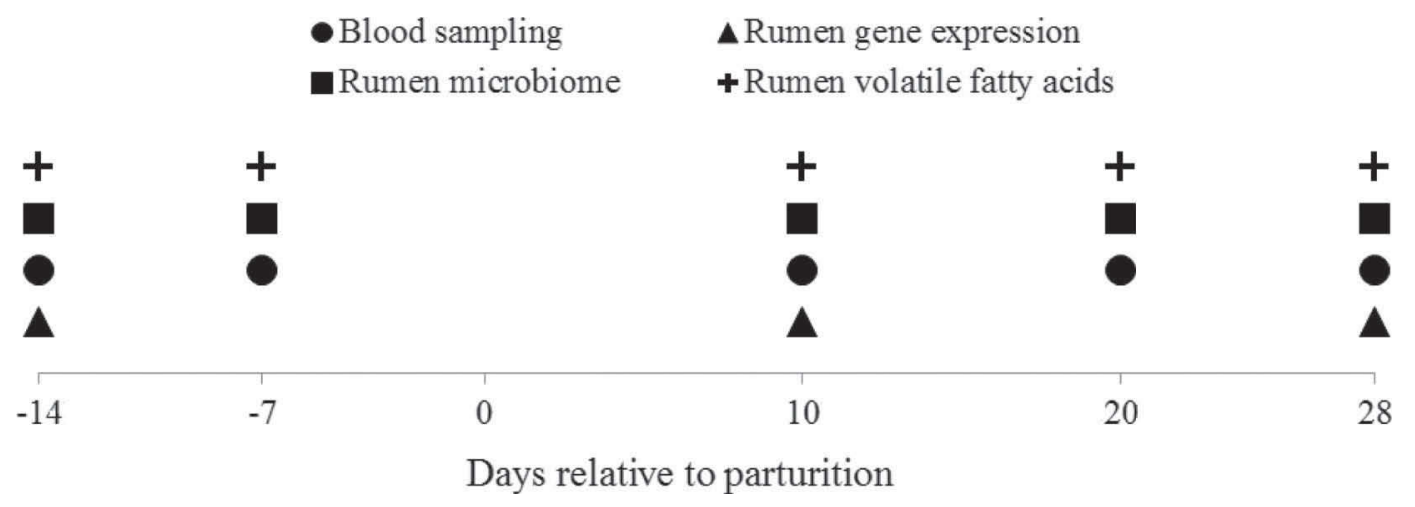

Figure 1. Sampling schedule during the experimental period. 
Table 2. Ruminal fermentation variables during the transition period in multiparous Holstein cows

\begin{tabular}{lccccccc}
\hline & \multicolumn{9}{c}{ Days relative to parturition } & & \\
\cline { 2 - 6 } Item & -14 & -7 & 10 & 20 & 28 & SEM & Effect \\
\hline pH & $6.84^{\mathrm{a}}$ & $6.82^{\mathrm{ab}}$ & $6.35^{\mathrm{b}}$ & $6.63^{\mathrm{ab}}$ & $6.32^{\mathrm{b}}$ & 0.137 & $*$ \\
Total VFA, mmol/L & $39.7^{\mathrm{a}}$ & 44.0 & 44.7 & 45.3 & 51.4 & 3.35 & $\mathrm{NS}$ \\
Acetate, $\%$ & $68.7^{\mathrm{a}}$ & $67.5^{\mathrm{a}}$ & $64.2^{\mathrm{ab}}$ & $64.5^{\mathrm{ab}}$ & $62.3^{\mathrm{b}}$ & 1.25 & $*$ \\
Propionate, $\%$ & $17.5^{\mathrm{c}}$ & 18.4 & 20.6 & 20.4 & 22.0 & 1.72 & $\dagger$ \\
Butyrate, $\%$ & $9.6^{\mathrm{c}}$ & $9.9^{\mathrm{bc}}$ & $10.9^{\mathrm{ab}}$ & $10.9^{\mathrm{ab}}$ & $11.3^{\mathrm{a}}$ & 0.38 & $* *$ \\
Isobutyrate, $\%$ & 1.2 & 1.1 & 1.0 & 1.1 & 1.0 & 0.14 & $\mathrm{NS}$ \\
Valerate, $\%$ & $1.0^{\mathrm{b}}$ & $1.1^{\mathrm{ab}}$ & $1.3^{\mathrm{ab}}$ & $1.2^{\mathrm{ab}}$ & $1.4^{\mathrm{a}}$ & 0.09 & $*$ \\
Isovalerate, $\%$ & 1.8 & 1.6 & 1.6 & 1.6 & 1.5 & 0.13 & $\mathrm{NS}$ \\
Caproate, $\%$ & 0.2 & 0.3 & 0.4 & 0.4 & 0.4 & 0.09 & $\dagger$ \\
Acetate:propionate & 4.1 & 3.7 & 3.3 & 3.2 & 2.9 & 0.26 & $\dagger$ \\
\hline
\end{tabular}

${ }^{\mathrm{a}-\mathrm{c}}$ Means with different superscripts are significantly different between days relative to parturition $(P<0.05)$. $\dagger P<0.10,{ }^{*} P<0.05$, and ${ }^{* *} P<0.01 ; \mathrm{NS}=$ not significant $(P>0.10)$.

Butyrate and valerate were higher after parturition $(P$ $<0.01$ and $P<0.05$, respectively), and isobutyrate and isovalerate remained unchanged $(P>0.05)$ during the experiment.

\section{Abundance of Major Microbial Species During the Peripartal Period}

Among the studied species, Butyrivibrio proteoclasticus, Eubacterium ruminantium, and Selenomonas ruminantium were the most abundant (Figure 2). However, the 7 individual species accounted for less than $1 \%(0.79$ to $0.97 \%)$ of the bacterial $16 \mathrm{~S}$ rRNA gene copies obtained from ruminal samples. Figure 2 depicts the abundance of the different ruminal microorganisms during the transition period. Eubacterium ruminantium and Selenomonas ruminantium were not affected $(P$ $>0.05$ ) by DIM. Megasphaera elsdenii and Prevotella bryantii increased $(P<0.01)$ significantly postpartum. Conversely, Butyrivibrio proteoclasticus decreased $(P<$ $0.01)$ gradually from -14 through 28 DIM. Fibrobacter succinogenes was affected by time, being lowest at 10 DIM $(P<0.05)$, and Anaerovibrio lipolytica had the lowest abundance $(P<0.01)$ at -7 DIM, followed by an increase by 20 DIM.

\section{Gene Expression in Ruminal Epithelium}

A total of 32 target genes were evaluated in the ruminal epithelium (Table 3). Four genes were not expressed (had cycle threshold values $>30$; IFNG, MPO, GPR 41, and IL6), and 12 genes were not affected because of time relative to parturition $P P A R A, P P A R D$, PPARG, CLDN1, CLDN4, SLC16A3, IGF1R, NFKB1, NFKBIA, TOLLIP, FOXO1, and TNF).

Metabolism, Insulin Signaling, and Tissue Development. Expression of 3-hydroxy-3-methylglutarylCoA synthase $2($ HMGCS2) was higher $(P<0.05)$ at 28
DIM compared with -14 and 10 DIM. The transcription factor retinoid $\mathrm{X}$ receptor $\alpha(R X R A)$ had higher $(P<0.05)$ expression before parturition compared with the first month of lactation. The lactate receptor GPR81 decreased $(P<0.05)$ from -14 to 10 DIM and then increased to prepartal values on $\mathrm{d} 28$.

Among insulin and IGF-related signaling genes, the ribosomal protein S6 kinase (RPS6KB1) decreased ( $P$ $<0.05)$ its expression gradually during the experimental period. A similar response was observed for MTOR, with a decrease $(P<0.05)$ in expression on d 10 relative to -14 followed by a return to prepartal expression on $\mathrm{d} 28$. The expression of the insulin receptor (INSR) was lower $(P<0.05)$ at 10 DIM compared with -14 and 28 DIM. However, the opposite was observed for IRS1, which had peak expression $(P<0.01)$ on $\mathrm{d} 10$ relative to -14 and $28 \mathrm{~d}$.

Transforming growth factor $\beta 1$ (TGFB1) had higher $(P<0.05)$ expression at 10 DIM compared with -14 and 28 DIM, and its receptor (TGFBR1) had higher $(P$ $<0.05)$ expression before parturition $(-14$ DIM) compared with the first month of lactation. Expression of epidermal growth factor receptor $(E G F R)$ did not differ $(P>0.05)$ between -14 and 10 DIM but increased on $\mathrm{d}$ 28. The opposite was observed for epiregulin (EREG), a protein that can function as EGFR ligand, which had a marked decrease $(P<0.05)$ in expression from -14 to 10 DIM, after which it returned to prepartal values on $\mathrm{d} 28$.

Tight Junctions and Immune Function Genes. Expression of occludin (OCLN) and tight junction protein 1 (TJP1) had lower $(P<0.05)$ expression at 10 compared with -14 DIM. The toll-like receptors ( TLR2 and TLR 4) and protein tyrosine phosphatase, receptor type, $\mathrm{C}(C D 45)$ had higher $(P<0.05)$ expression at -14 DIM compared with the first month of lactation, with lowest expression at 10 DIM and at 10 and 28 DIM for TLR2 and TLR4. Expression of interleukin-1 

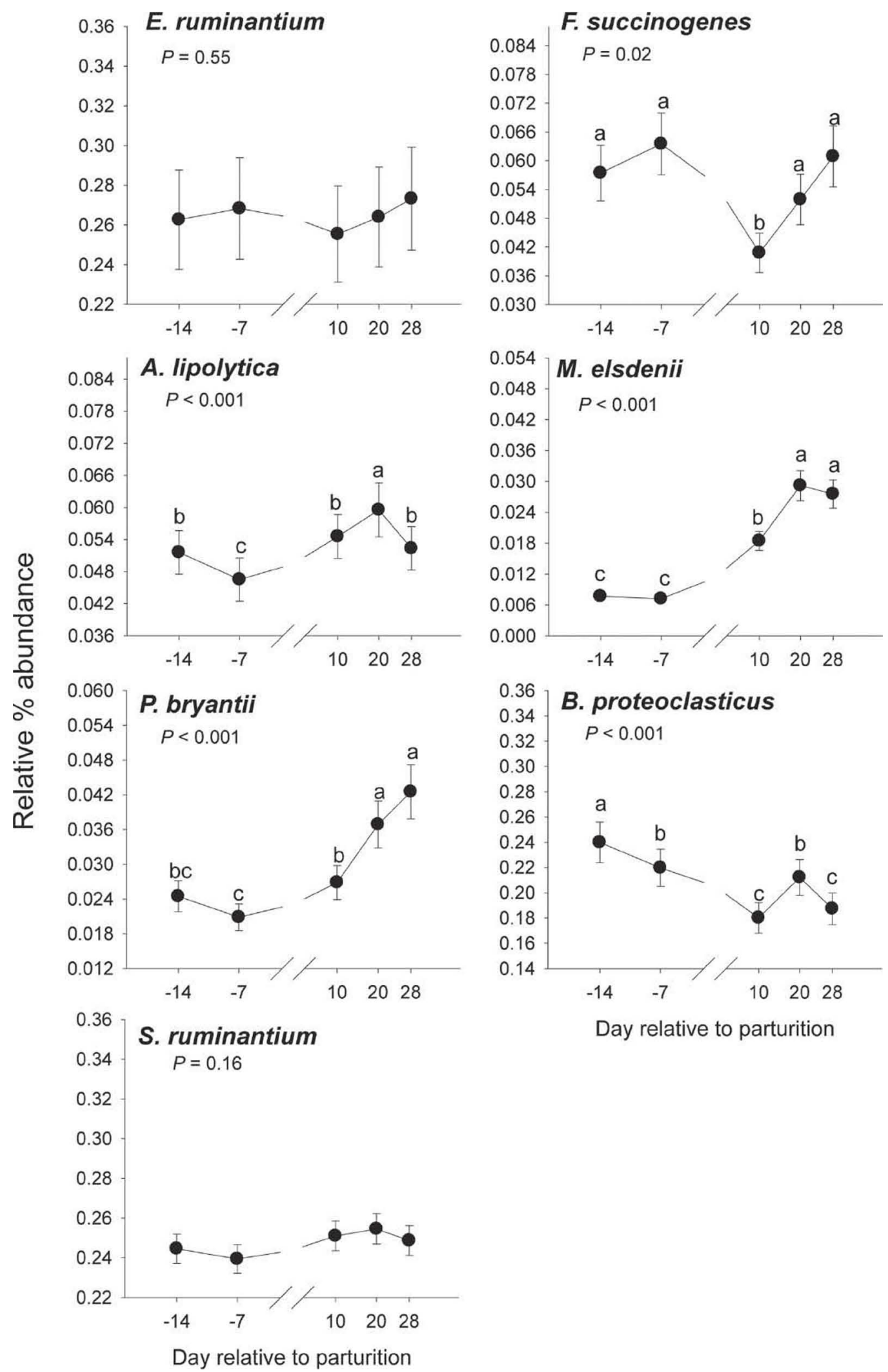

Day relative to parturition

Figure 2. Expression profiles of 7 ruminal microorganisms (Eubacterium ruminantium, Fibrobacter succinogenes, Anaerovibrio lipolytica, Megasphaera elsdenii, Prevotella bryantii, Butyrivibrio proteoclasticus, and Selenomonas ruminantium) during the peripartal period in Holstein dairy cows with ruminal cannulas. Different letters $(\mathrm{a}-\mathrm{c})$ indicate differences due to the main effect of time $(P<0.05)$. Error bars indicate standard error of the means. 
receptor-associated kinase 1 (IRAK1), which induces NFKB1 expression upon inflammation, was higher $(P$ $<0.05)$ on $\mathrm{d}-14$ and then decreased during the first month of lactation.

Membrane Transporters. The urea transporter (SLC14A1) and solute carrier family 16 (SLC16A1), which transports VFA, had an increase $(P<0.05)$ in expression at 28 DIM compared with -14 and 10 DIM.

\section{Blood Biomarkers}

Energy and Protein Metabolism. Excluding urea, all the blood biomarkers related to energy and protein metabolism were affected by time $(P<0.01$; Table 4$)$. The plasma concentration of glucose and creatinine was higher $(P<0.05)$ before parturition and decreased after calving, whereas the plasma concentration of NEFA and BHBA was lower $(P<0.05)$ from -14 to -7 DIM and increased after parturition, with the highest concentrations at 10 and 20 DIM for NEFA and BHBA, respectively. The concentration of cholesterol had the lowest values $(P<0.05)$ at 10 DIM, then increased to highest concentrations at 28 DIM.

Inflammation. Time around calving had a strong effect on the inflammatory and acute-phase protein markers, in particular, the plasma haptoglobin, which had a peak at 10 DIM $(P<0.05)$ compared with other times, and albumin and paraoxonase had highest concentrations before parturition $(P<0.05)$ and decreased after calving to lowest concentrations for the entire first month of lactation. The concentration of myeloperoxidase was highest $(P<0.05)$ during the dry period compared with lactation, and inversely, the ferric reducing antioxidant power had the highest $(P<$

Table 3. Relative mRNA expression and changes in mRNA expression among genes during the transition period in multiparous Holstein cows

\begin{tabular}{|c|c|c|c|c|c|}
\hline \multirow[b]{2}{*}{ Gene } & \multicolumn{3}{|c|}{ Days relative to parturition } & \multirow[b]{2}{*}{ SEM } & \multirow[b]{2}{*}{ Effect } \\
\hline & -14 & 10 & 28 & & \\
\hline \multicolumn{6}{|l|}{ Metabolism } \\
\hline$H M G C S 2$ & $-0.11^{\mathrm{b}}$ & $-0.16^{\mathrm{b}}$ & $0.18^{\mathrm{a}}$ & 0.10 & $* *$ \\
\hline PPARA & 0.09 & -0.07 & 0.03 & 0.10 & NS \\
\hline PPARD & -0.26 & -0.31 & -0.28 & 0.04 & NS \\
\hline$P P A R G$ & -0.10 & -0.27 & -0.15 & 0.09 & NS \\
\hline$R X R A$ & $0.15^{\mathrm{a}}$ & $-0.01^{\mathrm{b}}$ & $-0.04^{\mathrm{b}}$ & 0.05 & $*$ \\
\hline GPR81 & $-0.42^{\mathrm{a}}$ & $-0.82^{\mathrm{b}}$ & $-0.49^{\mathrm{a}}$ & 0.11 & $*$ \\
\hline \multicolumn{6}{|c|}{ Insulin and IGF signaling } \\
\hline MTOR & $-0.31^{\mathrm{ab}}$ & $-0.26^{\mathrm{a}}$ & $-0.39^{\mathrm{b}}$ & 0.05 & $*$ \\
\hline RPS6KB1 & $-0.25^{\mathrm{a}}$ & $-0.40^{\mathrm{b}}$ & $-0.52^{\mathrm{c}}$ & 0.05 & $* *$ \\
\hline$I N S R$ & $-0.09^{\mathrm{a}}$ & $-0.35^{\mathrm{b}}$ & $-0.16^{\mathrm{a}}$ & 0.08 & ** \\
\hline$I R S 1$ & $-0.07^{\mathrm{b}}$ & $0.15^{\mathrm{a}}$ & $0.02^{\mathrm{ab}}$ & 0.10 & $* *$ \\
\hline$I G F 1 R$ & -0.05 & -0.05 & -0.12 & 0.06 & NS \\
\hline FOXO1 & -0.09 & -0.11 & -0.18 & 0.06 & NS \\
\hline \multicolumn{6}{|c|}{ Tissue development } \\
\hline$T G F B 1$ & $-0.42^{\mathrm{b}}$ & $-0.24^{\mathrm{a}}$ & $-0.43^{\mathrm{b}}$ & 0.04 & $* *$ \\
\hline TGFBR 1 & $0.09^{\mathrm{a}}$ & $-0.10^{\mathrm{b}}$ & $-0.11^{\mathrm{b}}$ & 0.05 & $* *$ \\
\hline$E G F R$ & $-0.13^{\mathrm{b}}$ & $-0.20^{\mathrm{b}}$ & $0.07^{\mathrm{a}}$ & 0.06 & $*$ \\
\hline$E R E G$ & $-0.32^{\mathrm{a}}$ & $-0.84^{\mathrm{b}}$ & $-0.11^{\mathrm{a}}$ & 0.22 & $*$ \\
\hline \multicolumn{6}{|c|}{ Tight junctions } \\
\hline$C L D N 1$ & -0.03 & -0.11 & -0.09 & 0.09 & NS \\
\hline$C L D N_{4}$ & -0.25 & -0.05 & -0.24 & 0.14 & NS \\
\hline$O C L N$ & $0.04^{\mathrm{a}}$ & $-0.19^{\mathrm{b}}$ & $-0.10^{\mathrm{ab}}$ & 0.07 & $* *$ \\
\hline TJP1 & $-0.02^{\mathrm{a}}$ & $-0.18^{\mathrm{b}}$ & $-0.09^{\mathrm{ab}}$ & 0.06 & $*$ \\
\hline \multicolumn{6}{|c|}{ Immune function } \\
\hline$T L R 4$ & $0.15^{\mathrm{a}}$ & $-0.44^{\mathrm{b}}$ & $-0.53^{\mathrm{b}}$ & 0.09 & $* *$ \\
\hline TLR2 & $0.17^{\mathrm{a}}$ & $-0.09^{\mathrm{b}}$ & $-0.28^{\mathrm{b}}$ & 0.11 & $* *$ \\
\hline$C D 45$ & $0.14^{\mathrm{a}}$ & $-0.13^{\mathrm{b}}$ & $-0.08^{\mathrm{ab}}$ & 0.11 & $\dagger$ \\
\hline$T N F$ & 0.16 & -0.14 & 0.02 & 0.16 & NS \\
\hline$I R A K 1$ & $0.03^{\mathrm{a}}$ & $-0.12^{\mathrm{b}}$ & $-0.19^{\mathrm{b}}$ & 0.05 & $*$ \\
\hline$N F K B 1$ & -0.11 & -0.16 & -0.20 & 0.09 & NS \\
\hline NFKBIA & -0.11 & -0.01 & -0.09 & 0.06 & NS \\
\hline TOLLIP & -0.03 & -0.05 & -0.02 & 0.07 & NS \\
\hline \multicolumn{6}{|l|}{ Transporters } \\
\hline$S L C 14 A 1$ & $-0.46^{\mathrm{b}}$ & $-0.60^{\mathrm{b}}$ & $-0.25^{\mathrm{a}}$ & 0.09 & ** \\
\hline$S L C 16 A 1$ & $-0.25^{\mathrm{b}}$ & $-0.23^{\mathrm{ab}}$ & $-0.05^{\mathrm{a}}$ & 0.09 & $\dagger$ \\
\hline SLC16A3 & -0.17 & -0.14 & -0.05 & 0.07 & NS \\
\hline
\end{tabular}

${ }^{a-c}$ Means with different superscripts are significantly different between days relative to parturition $(P<0.05)$. $\dagger P<0.10,{ }^{*} P<0.05$, and ${ }^{* *} P<0.01 ; \mathrm{NS}=$ not significant $(P>0.10)$. 
$0.05)$ concentration during lactation compared with the late dry period.

Minerals and Liver Function. The concentration of $\mathrm{Mg}$ was the highest $(P<0.05)$ before parturition and decreased after calving (minimum at 10 DIM). Zinc concentration also decreased $(P<0.05)$ after calving compared with -20 DIM. Concentrations of biomarkers of liver function, including hepatic enzyme (aspartate amino-transferase, $\gamma$-glutamyl transferase) and bilirubin, were lowest $(P<0.05)$ during the dry period and increased markedly during lactation. Despite concentrations peaking at 10 DIM, they were maintained close to those levels for the entire first month of lactation.

\section{DISCUSSION}

\section{Blood Biomarkers}

The metabolic and inflammatory profiles observed in this experiment are typical of peripartal dairy cattle (Bionaz et al., 2007; Trevisi et al., 2009). The decreases of $\mathrm{BW}$ and $\mathrm{BCS}$ after parturition were in accordance with the high blood BHBA and NEFA concentrations, confirming that cows were in negative energy balance.
The characteristic inflammatory response around calving was more marked than in previous experiments (Bionaz et al., 2007; Bertoni et al., 2008; Trevisi et al., 2012). Cows with an optimal transition into lactation typically have lower peaks of haptoglobin and bilirubin (Bionaz et al., 2007; Bertoni et al., 2008). The sustained negative energy balance likely caused the persistence of the inflammatory response.

\section{Ruminal Fermentation and Abundance of Major Microbial Species}

The increase after parturition in Prevotella bryantii and Megasphaera elsdenii likely was a consequence of the higher DMI and fermentability of the diet reflected by the decrease in ruminal $\mathrm{pH}$ and acetate:propionate ratio. Anaerovibrio lipolytica also is important for lipid hydrolysis; thus, its higher proportion during the postpartal period could be partly explained by the inclusion of cottonseeds (a feedstuff with high lipid content) in the diet. In addition, Anaerovibrio lipolytica (just as Megasphaera elsdenii) can use lactate as a substrate for growth; thus, the increased proportion recorded after parturition also is in accordance with the higher diet

Table 4. Metabolite, mineral, enzyme, inflammatory, and oxidative stress biomarker concentrations in plasma during the transition period in multiparous Holstein cows

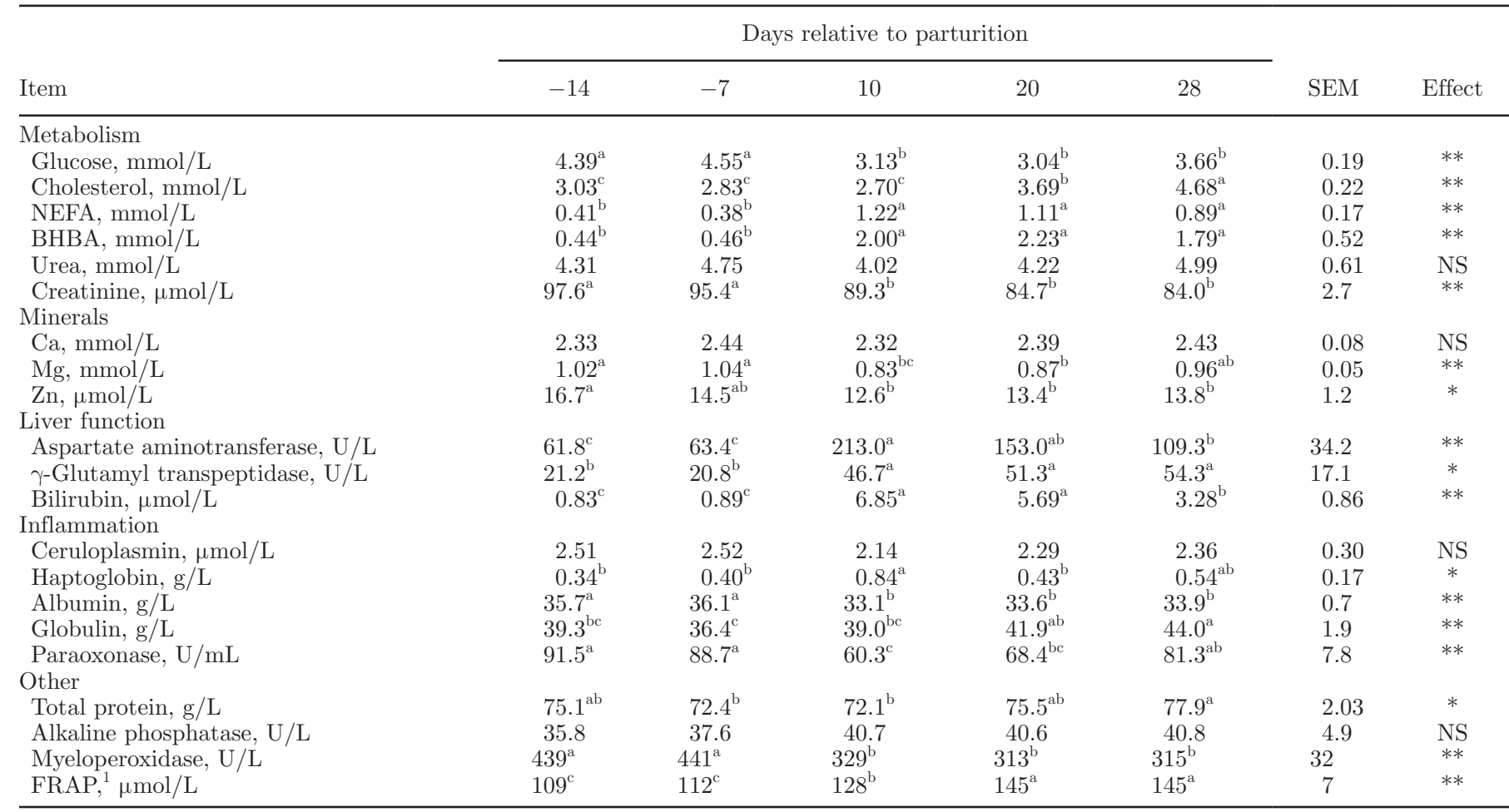

${ }^{\mathrm{a}-\mathrm{c}}$ Means with different superscripts are significantly different between days relative to parturition $(P<0.05)$.

${ }^{1}$ Ferric-reducing antioxidant power.

${ }^{*} P<0.05,{ }^{*} P<0.01 ; \mathrm{NS}=$ not significant $(P>0.10)$. 
fermentability. Overall, our data confirmed previous observations of increases in Streptococcus bovis, Lactobacillus spp., Ruminobacter amylophilus, Prevotella ruminicola, Megasphaera elsdenii, and Selenomonas ruminantium when the diet changes from high forage to high concentrate (Tajima et al., 2001; Fernando et al., 2010).

Increasing concentrate inclusion in the diet leads to a decrease of fibrolytic bacteria such as Fibrobacter succinogenes, Ruminococcus flavefaciens, and Butyrivibrio fibrisolvens (Fernando et al., 2010). The observed decreases in Butyrivibrio proteoclasticus and Fibrobacter succinogenes (through at least 10 DIM) agree with previous data. Wang et al. (2012) reported a marked increase of Fibrobacter succinogenes after parturition. The gradual increase in Fibrobacter succinogenes from 10 through 28 DIM underscores the complexity of the rumen microbiota and the fact that differences in the microbiome composition are not only related to diet but also to individual animals (Jami and Mizrahi, 2012).

It is noteworthy that Selenomonas ruminantium did not change across time, unlike previous data from a transition study (Wang et al., 2012). This bacterium uses lactate among other substrates and usually proliferates when high-concentrate diets are fed. It should be noted that cows in the present study were fed a higherenergy diet during the last $21 \mathrm{~d}$ prepartum designed to resemble the lactation diet. It could be possible that such a management approach created ruminal conditions that minimized abrupt changes in this bacterium.

\section{Gene Expression in Ruminal Epithelium During Transition}

Ketogenesis. The enzyme encoded by HMGCS2 catalyzes the rate-limiting step in the synthesis of acetoacetate and BHBA. In nonruminants, the level of HMGCS2 mRNA is strongly correlated with the rate of ketogenesis (Hegardt, 1999); thus, changes in mRNA are important in overall control of pathway flux. An increase of ketone body precursors such as butyrate in the intestine of nonruminants (Cherbuy et al., 1995, 2004) or in the rumen enhances ketogenesis in the epithelium (Harmon et al., 1991; Penner et al., 2009). The increase in expression from prepartum to d 28 agrees with the gradual increase in ruminal butyrate concentration over time. The relative percentage mRNA abundance of $H M G C S 2$ accounted for approximately $58 \%$ of the total genes examined (data not shown), which agrees with data from Naeem et al. (2012) measured in 5- to 10-wkold calves. Overall, the data highlight the central role of HMGCS2 in coordinating ruminal ketogenic flux.

PPAR and Insulin Resistance. Although the expression of the PPAR did not change during the transi- tion period, the fact that $R X R A$ had a high percentage of relative mRNA abundance $(8.7 \%)$ and its expression decreased through the transition period indicate that it can indirectly limit the PPAR response because formation of the complex between PPAR and retinoic $\mathrm{X}$ receptors (RXR) is essential for transcriptional activity (Michalik et al., 2004; Kota et al., 2005). One key function that could be impaired because of reduction in formation of the PPARG/RXRA is cellular insulin sensitivity (Kota et al., 2005; Leonardini et al., 2009). This idea is supported by the lower expression of INSR at 10 DIM. Inhibition of INSR is one major mechanism responsible for insulin resistance (Pessin and Saltiel, 2000).

Contrary to the INSR response, the reduction of expression of RPS6KB1 after calving seems to indicate the existence of a feedback system to reduce the insulin resistance potentially driven by the inherently low uptake of glucose by ruminal epithelium. In nonruminants, the upregulation of the mTOR/RPS6KB1 pathway at higher uptakes of AA and glucose decreases the phosphorylation of insulin receptor substrate 1 and consequently the action of insulin on nutrient uptake by cells (Um et al., 2006). The absence of RPS6KB1 alone increases cellular insulin sensitivity (Manning, 2004). Taken together, the data suggest that the ruminal epithelium experiences insulin resistance as a mechanism to increase the availability of glucose, AA, and FA to the mammary gland (Bell and Bauman, 1997).

Tight Junctions. The tight junctions (TJ) help regulate the permeability of epithelial barriers and prevent the translocation of LPS and other toxins (Ulluwishewa et al., 2011). The claudins and occludins are proteins that form the TJ structure and are associated with different peripheral membrane proteins such as TJP1 located on the intracellular side of the plasma membrane (Fanning et al., 1999; Schneeberger and Lynch, 2004). Knowledge of the regulation of rumen TJ, and the epithelial permeability, is extremely limited (Penner et al., 2011).

Using microscopy, Steele et al. (2015) reported morphological changes in the ruminal epithelium after calving without changes in mRNA expression of cell adhesion proteins (Steele et al., 2015). In a recent study, Liu et al. (2013) reported that a high-grain diet in goats caused massive disruption of ruminal epithelial TJ with profound alterations in ruminal epithelial structure and changes in TJ protein expression, in particular claudin-4, occludin, and TJP1. Our results suggest that during the transition period the ruminal epithelium experiences a slight impairment of barrier function. The intake of a diet with higher fermentability after calving and the ensuing increase in bacterial species capable of rapid fermentation induce a higher VFA production 
and, consequently, a decrease of ruminal pH. Furthermore, the increase of gram-negative bacteria (which are sources of LPS) could have contributed to greater concentration of ruminal fluid LPS leading to an impairment of TJ function (Chin et al., 2006). Further information on the biology of TJ could be useful for developing strategies to minimize the potential for the translocation of bacteria and toxins across the ruminal epithelia.

Immune and Inflammatory Genes. The presence of TLR in bovine ruminal epithelium has been reported previously (Chen et al., 2012; Malmuthuge et al., 2012; Trevisi et al., 2014). The decrease in TLR, IRAK1, and CD45 expression after calving is indicative that the ruminal epithelium may be an important component of the host immune system. The decrease in expression of $C D 45$ (a marker of immune cells) after calving is suggestive of a lower relative abundance of immune cells on the epithelial tissue. This effect is reasonable considering the fact that growth of ruminal epithelial tissue mass increases markedly after calving (Bannink et al., 2008; Martens et al., 2012).

The activation of TLR after the recognition of membrane components of bacteria (LPS, peptidoglycan, and lipoteichoic acid) induces an inflammatory response (Medzhitov, 2008; Kawai and Akira, 2009). Chen et al. (2012) detected a higher expression of TLR2 and TLR4 in ruminal epithelium of steers classified as acidosis resistant compared with steers classified as acidosis susceptible and concluded that the decrease in expression of these receptors may render animals more susceptible to inflammatory stimuli originating from the ruminal environment (Chen et al., 2012).

Catalani et al. (2010) detected a decrease of expression of TLR4 in peripheral blood mononuclear cells in cows after calving and hypothesized this was a mechanism of endotoxin tolerance. Mechanisms of endotoxin tolerance are present in intestinal epithelial cells and act to avoid deleterious TLR activation by Toll-interacting protein (Abreu, 2010). It is possible that, just as in the intestine, after calving the ruminal epithelium adapts to an increase in rumen LPS content, that is, due to the higher diet fermentability leading to greater VFA production and suboptimal $\mathrm{pH}$ driving greater bacterial lysis.

The consequences of decreasing expression of TLR receptors on ruminal epithelium are unknown. However, damages of epithelium permeability (Minuti et al., 2013, 2014) make the interaction between LPS and other bacterial immunogens and resident immune cells (macrophage and dendritic cell) more probable, hence, increasing the risk of inflammatory events originating from the gastrointestinal tract (Minuti et al., 2013, 2014).
Cellular Transporters. In our study, the relative high percentage mRNA abundance of MCT1 (10.1\%) compared with MCT4 (0.05\%) confirms data from a previous study in reindeer (Koho et al., 2005) and immunohistochemistry staining data from dairy cows (Kirat et al., 2007). The MCT1 plays a direct role in the shuttling of intracellular VFA, lactate, and ketone bodies across the basolateral membrane of the epithelium toward the bloodstream (Müller et al., 2002; Aschenbach et al., 2011). Clearly, the importance of MCT1 in the ruminal epithelium is substantial.

The higher expression of MCT1 at 28 DIM appears related to a decrease in intracellular acid load as a consequence of an increase in concentration and absorption of VFA from the lumen of the rumen (Metzler-Zebeli et al., 2013). This idea is supported by previous studies in ruminants (Koho et al., 2011; Kuzinski and Rontgen, 2011; Metzler-Zebeli et al., 2013) where an increase of MCT1 expression was detected following dietary treatments that enhanced the amount of fermentable substrates and consequently the amount of VFA produced. Considering that at 28 DIM we detected a higher expression of both $M C T 1$ and $H M G C S 2$, it is possible that an increase in concentration of ketone bodies within the ruminal epithelial cell led to an increase in export into the bloodstream.

The urea transporter SLC14A1 (also known as UTB) is a membrane protein that plays a role in the entry of urea from blood into the digestive tract and consequently participates in urea nitrogen recycling (Stewart, 2011). Sunny et al. (2007) suggested that the transfer of urea $\mathrm{N}$ to the gastrointestinal tract (transporter mediated or diffusion) is highly related to plasma urea concentration. Simmons et al. (2009) detected a higher expression of ruminal UTB in steers fed a concentratebased diet compared with steers fed a silage-based diet and demonstrated that diet can induce changes in UTB urea transporter expression. Considering that both diets were isoproteic, they also suggested that the ruminal butyrate concentration may play a role in the long-term regulation of UTB expression (Simmons et al., 2009).

In our experiment the gradual increase in expression of SLC14A1 after calving was likely related to both ruminal butyrate and blood urea concentration, suggesting that, in the transition dairy cow, both mechanisms are important. The fact that both SLC14A1 and $S L C 16 A 1$ reached peak expression at 28 DIM indicates that DMI and rumen digestion are important stimuli for these genes. Further studies that elucidate the adaptive mechanisms of these transporters at the ruminal epithelial level could help manipulate the efficiency of rumen function and enhance nutrient utilization. 
Tissue Development. The results for TGFB1 and EREG agree with the recent study by Steele et al. (2015) using a similar experimental timeline. However, the finding of an upregulation of $E G F R$, a member of the epidermal growth factor family (Shirakata et al., 2000), at the end of the peripartal period is opposite to the observation by Steele et al. (2015). An upregulation of EREG expression can induce autocrine growth factors leading to greater keratinocyte differentiation (Shirakata et al., 2000). Signaling via EGFR is essential for keratinocyte proliferation (Bektas et al., 2013); thus, the similar expression of EREG and EGFR agrees with the fact that epiregulin can serve as ligand for EGFR.

The present data support a role for TGFB1 in the regulation of growth and differentiation of rumen epithelium in early lactation (Connor et al., 2014; Steele et al., 2015). The TGFB1 protein mediates several physiological processes, including inhibition of cell proliferation, activation of apoptosis, and cellular differentiation (Massagué et al., 2000; Moustakas et al., 2002). Connor et al. (2014) observed an increase in TGFB1 expression in ruminating calves and hypothesized it was a mechanism to reduce calf ruminal cell proliferation likely mediated by butyrate from rumen fermentation. However, in adult ruminants no effect of butyrate on TGFB1 in ruminal epithelium was observed (Baldwin et al., 2012). Connor et al. (2014) suggested that TGFB1 may play different roles in adult than young ruminal epithelium.

During the adaptation from a low- to a high-fermentable diet, the ruminal epithelia respond by increasing their proliferative capacity to maximize the absorptive surface (Sakata and Tamate, 1978; Sakata and Yajima, 1984) and by reducing cellular apoptosis (Penner et al., 2011). Butyrate is the main stimulator of these events (Sakata and Tamate, 1978; Sakata and Yajima, 1984). In our study, the earlier increase of TGFB1 (10 DIM) and the reduction of TGFBR1, EGFR, and EREG after calving suggest an initial period of cell proliferation arrest followed by a feedback mechanism to promote the proliferative capacity of the epithelium. It is not clear if these events are mediated by the increase of butyrate in the rumen, intracellular factors, or the endocrine environment of the animal.

\section{CONCLUSIONS}

Understanding ruminal epithelium physiology during transition will help nutritionists to develop strategies to enhance dairy cow health and production in early lactation (Steele et al., 2015). Several processes involved in ruminal epithelium adaptations to degree of diet fermentability are closely related to the production of VFA, especially butyrate (Sakata and Tamate, 1978; Sakata and Yajima, 1984). Similarly, ruminal micro- biome structure is related to production traits such as milk production (Jami et al., 2014; Lima et al., 2015). These relationships have been tentatively explained by the specific fermentation end products (VFA) likely produced by the different microorganisms. However, not only VFA are responsible of these changes, for example, SARA induced with pelleted alfalfa did not cause inflammation compared with SARA induced with a high-grain load. Thus, other factors beyond the rumen itself likely contribute to changes in ruminal epithelial metabolism. The connections among ruminal fermentation, the ensuing ruminal epithelium adaptations, and the consequence on systemic responses (e.g., immunometabolism) of the cow remain unclear. Whether microbial metabolism could affect epithelial gene expression via metabolites remains uncertain. Because of challenges with in vitro incubation of anaerobic organisms, only few have been studied deeply (Morgavi et al., 2013). Metabolic cooperation, along with synergism, predation, cell-cell signaling, and structural organization, likely allows certain bacteria to adapt their metabolism according to changes in diet and the presence of other microorganisms (Morgavi et al., 2013). Future studies using more advanced technologies (e.g., transcriptomics, metagenomics, metabolomics) and suitable bioinformatics tools will be helpful in enhancing the systems understanding of the whole animal during the peripartal period.

\section{ACKNOWLEDGMENTS}

Saleh Alqarni was supported by an MS fellowship from the Saudi Arabian Cultural Mission (Washington, DC). Support for analyses was provided in part by Hatch funds under project ILLU-538-914, National Institute of Food and Agriculture, Washington, DC.

\section{REFERENCES}

Abreu, M. T. 2010. Toll-like receptor signalling in the intestinal epithelium: How bacterial recognition shapes intestinal function. Nat. Rev. Immunol. 10:131-144. http://dx.doi.org/10.1038/nri2707.

Aschenbach, J. R., G. B. Penner, F. Stumpff, and G. Gäbel. 2011. Ruminant Nutrition Symposium: Role of fermentation acid absorption in the regulation of ruminal pH. J. Anim. Sci. 89:1092-1107. http://dx.doi.org/10.2527/jas.2010-3301.

Baldwin, R. L., S. Wu, W. Li, C. Li, B. J. Bequette, and R. W. Li. 2012. Quantification of transcriptome responses of the rumen epithelium to butyrate infusion using RNA-seq technology. Gene Regul. Syst. Bio. 6:67-80. http://dx.doi.org/10.4137/GRSB.S9687.

Bannink, A., J. France, S. Lopez, W. J. J. Gerrits, E. Kebreab, S. Tamminga, and J. Dijkstra. 2008. Modelling the implications of feeding strategy on rumen fermentation and functioning of the rumen wall. Anim. Feed Sci. Technol. 143:3-26. http://dx.doi. org/10.1016/j.anifeedsci.2007.05.002.

Bannink, A., W. J. J. Gerrits, J. France, and J. Dijkstra. 2012. Variation in rumen fermentation and the rumen wall during the transition period in dairy cows. Anim. Feed Sci. Technol. 172:80-94. http://dx.doi.org/10.1016/j.anifeedsci.2011.12.010. 
Bektas, M., P. S. Jolly, P. Berkowitz, M. Amagai, and D. S. Rubenstein. 2013. A pathophysiologic role for epidermal growth factor receptor in pemphigus acantholysis. J. Biol. Chem. 288:9447-9456. http://dx.doi.org/10.1074/jbc.M112.438010.

Bell, A. W., and D. E. Bauman. 1997. Adaptations of glucose metabolism during pregnancy and lactation. J. Mammary Gland Biol. Neoplasia 2:265-278

Bertoni, G., E. Trevisi, X. Han, and M. Bionaz. 2008. Effects of inflammatory conditions on liver activity in puerperium period and consequences for performance in dairy cows. J. Dairy Sci. 91:33003310. http://dx.doi.org/10.3168/jds.2008-0995.

Bionaz, M., E. Trevisi, L. Calamari, F. Librandi, A. Ferrari, and G. Bertoni. 2007. Plasma paraoxonase, health, inflammatory conditions, and liver function in transition dairy cows. J. Dairy Sci. 90:1740-1750. http://dx.doi.org/10.3168/jds.2006-445

Catalani, E., M. Amadori, A. Vitali, U. Bernabucci, A. Nardone, and N. Lacetera. 2010. The Hsp72 response in peri-parturient dairy cows: Relationships with metabolic and immunological parameters. Cell Stress Chaperones 15:781-790. http://dx.doi.org/10.1007/ s12192-010-0186-x.

Chen, Y., M. Oba, and L. L. Guan. 2012. Variation of bacterial communities and expression of Toll-like receptor genes in the rumen of steers differing in susceptibility to subacute ruminal acidosis. Vet. Microbiol. 159:451-459. http://dx.doi.org/10.1016/j. vetmic.2012.04.032.

Cherbuy, C., C. Andrieux, E. Honvo-Houeto, M. Thomas, C. Ide, N. Druesne, C. Chaumontet, B. Darcy-Vrillon, and P.-H. Duée. 2004 Expression of mitochondrial HMGCoA synthase and glutaminase in the colonic mucosa is modulated by bacterial species. Eur. J. Biochem. 271:87-95.

Cherbuy, C., B. Darcy-Vrillon, M. T. Morel, J. P. Pégorier, and P. H Duée. 1995. Effect of germfree state on the capacities of isolated rat colonocytes to metabolize n-butyrate, glucose, and glutamine. Gastroenterology 109:1890-1899

Chin, A. C., A. N. Flynn, J. P. Fedwick, and A. G. Buret. 2006. The role of caspase-3 in lipopolysaccharide-mediated disruption of intestinal epithelial tight junctions. Can. J. Physiol. Pharmacol. 84:1043-1050. http://dx.doi.org/10.1139/y06-056.

Connor, E. E., R. L. Baldwin, M. P. Walker, S. E. Ellis, C. Li, S. Kahl, H. Chung, and R. W. Li. 2014. Transcriptional regulators transforming growth factor- $\beta 1$ and estrogen-related receptor- $\alpha$ identified as putative mediators of calf rumen epithelial tissue development and function during weaning. J. Dairy Sci. 97:4193-4207. http://dx.doi.org/10.3168/jds.2013-7471.

Dionissopoulos, L., O. AlZahal, M. A. Steele, J. C. Matthews, and B. W. McBride. 2014. Transcriptomic changes in ruminal tissue induced by the periparturient transition in dairy cows. Am. J. Anim. Vet. Sci. 9:36-45. http://dx.doi.org/10.3844/ajavsp.2014.36.45

Fanning, A. S., L. L. Mitic, and J. M. Anderson. 1999. Transmembrane proteins in the tight junction barrier. J. Am. Soc. Nephrol. 10:1337-1345

Fernando, S. C., H. T. Purvis, F. Z. Najar, L. O. Sukharnikov, C. R. Krehbiel, T. G. Nagaraja, B. A. Roe, and U. Desilva. 2010. Rumen microbial population dynamics during adaptation to a highgrain diet. Appl. Environ. Microbiol. 76:7482-7490. http://dx.doi. org/10.1128/AEM.00388-10.

Graugnard, D. E., M. Bionaz, E. Trevisi, K. M. Moyes, J. L. SalakJohnson, R. L. Wallace, J. K. Drackley, G. Bertoni, and J. J. Loor. 2012. Blood immunometabolic indices and polymorphonuclear neutrophil function in peripartum dairy cows are altered by level of dietary energy prepartum. J. Dairy Sci. 95:1749-1758. http:// dx.doi.org/10.3168/jds.2011-4579.

Graugnard, D. E., K. M. Moyes, E. Trevisi, M. J. Khan, D. Keisler, J K. Drackley, G. Bertoni, and J. J. Loor. 2013. Liver lipid content and inflammometabolic indices in peripartal dairy cows are altered in response to prepartal energy intake and postpartal intramammary inflammatory challenge. J. Dairy Sci. 96:918-935. http:// dx.doi.org/10.3168/jds.2012-5676.

Harmon, D. L., K. L. Gross, C. R. Krehbiel, K. K. Kreikemeier, M. L. Bauer, and R. A. Britton. 1991. Influence of dietary forage and energy intake on metabolism and acyl-CoA synthetase activity in bovine ruminal epithelial tissue. J. Anim. Sci. 69:4117-4127.

Hegardt, F.G. 1999. Mitochondrial 3-hydroxy-3-methylglutaryl-CoA synthase: A control enzyme in ketogenesis. Biochem. J. 338(Pt. 3):569-582.

Hernandez-Sanabria, E., L. A. Goonewardene, Z. Wang, O. N. Durunna, S. S. Moore, and L. L. Guan. 2012. Impact of feed efficiency and diet on adaptive variations in the bacterial community in the rumen fluid of cattle. Appl. Environ. Microbiol. 78:1203-1214. http://dx.doi.org/10.1128/AEM.05114-11.

Jami, E., and I. Mizrahi. 2012. Composition and similarity of bovine rumen microbiota across individual animals. PLoS ONE 7:e33306 http://dx.doi.org/10.1371/journal.pone.0033306.

Jami, E., B. A. White, and I. Mizrahi. 2014. Potential role of the bovine rumen microbiome in modulating milk composition and feed efficiency. PLoS ONE 9:e85423 http://dx.doi.org/10.1371/journal. pone. 0085423

Kawai, T., and S. Akira. 2009. The roles of TLRs, RLRs and NLRs in pathogen recognition. Int. Immunol. 21:317-337. http://dx.doi org/10.1093/intimm/dxp017.

Khafipour, E., S. Li, J. C. Plaizier, and D. O. Krause. 2009. Rumen microbiome composition determined using two nutritional models of subacute ruminal acidosis. Appl. Environ. Microbiol. 75:71157124. http://dx.doi.org/10.1128/AEM.00739-09.

Kirat, D., Y. Matsuda, N. Yamashiki, H. Hayashi, and S. Kato. 2007. Expression, cellular localization, and functional role of monocarboxylate transporter 4 (MCT4) in the gastrointestinal tract of ruminants. Gene 391:140-149. http://dx.doi.org/10.1016/j. gene.2006.12.020

Koho, N., V. Maijala, H. Norberg, M. Nieminen, and A. R. Pösö. 2005. Expression of MCT1, MCT2 and MCT4 in the rumen, small intestine and liver of reindeer (Rangifer tarandus tarandus L.). Comp. Biochem. Physiol. A Mol. Integr. Physiol. 141:29-34. http:// dx.doi.org/10.1016/j.cbpb.2005.03.003.

Koho, N. M., J. Taponen, H. Tiihonen, M. Manninen, and A. R. Pösö. 2011. Effects of age and concentrate feeding on the expression of MCT 1 and CD147 in the gastrointestinal tract of goats and Hereford finishing beef bulls. Res. Vet. Sci. 90:301-305. http://dx.doi. org/10.1016/j.rvsc.2010.06.002.

Kota, B. P., T. H.-W. Huang, and B. D. Roufogalis. 2005. An overview on biological mechanisms of PPARs. Pharmacol. Res. 51:85-94. http://dx.doi.org/10.1016/j.phrs.2004.07.012.

Kuzinski, J., and M. Rontgen. 2011. The mRNA and protein expression of ruminal MCT1 is increased by feeding a mixed hay/concentrate diet compared with hay ad libitum diet (Short Communication). Arch. Tierzucht. 54:280-286.

Leonardini, A., L. Laviola, S. Perrini, A. Natalicchio, and F. Giorgino. 2009. Cross-talk between PPARgamma and insulin signaling and modulation of insulin sensitivity. PPAR Res. 2009:Article \#818945. http://dx.doi.org/10.1155/2009/818945.

Lima, F. S., G. Oikonomou, S. F. Lima, M. L. S. Bicalho, E. K. Ganda, J. C. Oliveira Filho, G. Lorenzo, P. Trojacanec, and R. C. Bicalho. 2015. Characterization of prepartum and postpartum rumen fluid microbiomes and its correlation with production traits in dairy cows. Appl. Environ. Microbiol. 81:1327-1337. http:// dx.doi.org/10.1128/AEM.03138-14.

Liu, J., T. Xu, Y. Liu, W. Zhu, and S. Mao. 2013. A high-grain diet causes massive disruption of ruminal epithelial tight junctions in goats. Am. J. Physiol. Regul. Integr. Comp. Physiol. 305:R232R241. http://dx.doi.org/10.1152/ajpregu.00068.2013.

Malmuthuge, N., M. Li, P. Fries, P. J. Griebel, and L. L. Guan. 2012 Regional and age dependent changes in gene expression of Toll-like receptors and key antimicrobial defense molecules throughout the gastrointestinal tract of dairy calves. Vet. Immunol. Immunopathol. 146:18-26. http://dx.doi.org/10.1016/j.vetimm.2012.01.010.

Manning, B. D. 2004. Balancing Akt with S6K: Implications for both metabolic diseases and tumorigenesis. J. Cell Biol. 167:399-403. http://dx.doi.org/10.1083/jcb.200408161.

Martens, H., I. Rabbani, Z. Shen, F. Stumpff, and C. Deiner. 2012. Changes in rumen absorption processes during transition. Anim. 
Feed Sci. Technol. 172:95-102. http://dx.doi.org/10.1016/j. anifeedsci.2011.12.011.

Massagué, J., S. W. Blain, and R. S. Lo. 2000. TGFbeta signaling in growth control, cancer, and heritable disorders. Cell 103:295-309.

Medzhitov, R. 2008. Origin and physiological roles of inflammation. Nature 454:428-435. http://dx.doi.org/10.1038/nature07201.

Metzler-Zebeli, B. U., M. Hollmann, S. Sabitzer, L. Podstatzky-Lichtenstein, D. Klein, and Q. Zebeli. 2013. Epithelial response to high-grain diets involves alteration in nutrient transporters and $\mathrm{Na}+/ \mathrm{K}+$-ATPase mRNA expression in rumen and colon of goats. J. Anim. Sci. 91:4256-4266. http://dx.doi.org/10.2527/jas.20125570 .

Michalik, L., B. Desvergne, and W. Wahli. 2004. Peroxisome-proliferator-activated receptors and cancers: Complex stories. Nat. Rev. Cancer 4:61-70. http://dx.doi.org/10.1038/nrc1254.

Minuti, A., S. Ahmed, E. Trevisi, F. Piccioli-Cappelli, G. Bertoni, and P. Bani. 2013. Assessment of gastrointestinal permeability by lactulose test in sheep after repeated indomethacin treatment. J. Anim. Sci. 91:5646-5653. http://dx.doi.org/10.2527/jas.20136729 .

Minuti, A., S. Ahmed, E. Trevisi, F. Piccioli-Cappelli, G. Bertoni, N. Jahan, and P. Bani. 2014. Experimental acute rumen acidosis in sheep: Consequences on clinical, rumen, and gastrointestinal permeability conditions and blood chemistry. J. Anim. Sci. 92:39663977. http://dx.doi.org/10.2527/jas.2014-7594.

Morgavi, D. P., W. J. Kelly, P. H. Janssen, and G. T. Attwood. 2013. Rumen microbial (meta)genomics and its application to ruminant production. Animal 7(Suppl. 1):184-201. http://dx.doi. org $/ 10.1017 /$ S1751731112000419.

Moustakas, A., K. Pardali, A. Gaal, and C. H. Heldin. 2002. Mechanisms of TGF-beta signaling in regulation of cell growth and differentiation. Immunol. Lett. 82:85-91.

Müller, F., K. Huber, H. Pfannkuche, J. R. Aschenbach, G. Breves, and G. Gäbel. 2002. Transport of ketone bodies and lactate in the sheep ruminal epithelium by monocarboxylate transporter 1 . Am. J. Physiol. Gastrointest. Liver Physiol. 283:G1139-G1146. http:// dx.doi.org/10.1152/ajpgi.00268.2001.

Naeem, A., J. K. Drackley, J. Stamey, and J. J. Loor. 2012. Role of metabolic and cellular proliferation genes in ruminal development in response to enhanced plane of nutrition in neonatal Holstein calves. J. Dairy Sci. 95:1807-1820. http://dx.doi.org/10.3168/ jds.2011-4709.

NRC. 2001. Nutrient Requirements of Dairy Cattle. 7th rev. ed. Natl. Acad. Press, Washington, DC.

Penner, G. B., M. A. Steele, J. R. Aschenbach, and B. W. McBride. 2011. Ruminant Nutrition Symposium: Molecular adaptation of ruminal epithelia to highly fermentable diets. J. Anim. Sci. 89:1108-1119. http://dx.doi.org/10.2527/jas.2010-3378.

Penner, G. B., M. Taniguchi, L. L. Guan, K. A. Beauchemin, and M. Oba. 2009. Effect of dietary forage to concentrate ratio on volatile fatty acid absorption and the expression of genes related to volatile fatty acid absorption and metabolism in ruminal tissue. J. Dairy Sci. 92:2767-2781. http://dx.doi.org/10.3168/jds.2008-1716.

Pessin, J. E., and A. R. Saltiel. 2000. Signaling pathways in insulin action: Molecular targets of insulin resistance. J. Clin. Invest. 106:165-169. http://dx.doi.org/10.1172/JCI10582.

Petri, R. M., T. Schwaiger, G. B. Penner, K. A. Beauchemin, R. J. Forster, J. J. McKinnon, and T. A. McAllister. 2013. Characterization of the core rumen microbiome in cattle during transition from forage to concentrate as well as during and after an acidotic challenge. PLoS ONE 8:e83424 http://dx.doi.org/10.1371/journal. pone.0083424.

Pitta, D. W., S. Kumar, B. Vecchiarelli, D. J. Shirley, K. Bittinger, L. D. Baker, J. D. Ferguson, and N. Thomsen. 2014. Temporal dynamics in the ruminal microbiome of dairy cows during the transition period. J. Anim. Sci. 92:4014-4022. http://dx.doi. org/10.2527/jas.2014-7621.

Sakata, T., and H. Tamate. 1978. Rumen epithelial cell proliferation accelerated by rapid increase in intraruminal butyrate. J. Dairy Sci. 61:1109-1113. http://dx.doi.org/10.3168/jds.S00220302(78)83694-7.

Sakata, T., and T. Yajima. 1984. Influence of short chain fatty acids on the epithelial cell division of digestive tract. Q. J. Exp. Physiol. 69:639-648.

Schneeberger, E. E., and R. D. Lynch. 2004. The tight junction: A multifunctional complex. Am. J. Physiol. Cell Physiol. 286:C1213C1228. http://dx.doi.org/10.1152/ajpcell.00558.2003.

Shirakata, Y., T. Komurasaki, H. Toyoda, Y. Hanakawa, K. Yamasaki, S. Tokumaru, K. Sayama, and K. Hashimoto. 2000. Epiregulin, a novel member of the epidermal growth factor family, is an autocrine growth factor in normal human keratinocytes. J. Biol. Chem. 275:5748-5753.

Simmons, N. L., A. S. Chaudhry, C. Graham, E. S. Scriven, A. Thistlethwaite, C. P. Smith, and G. S. Stewart. 2009. Dietary regulation of ruminal bovine UT-B urea transporter expression and localization. J. Anim. Sci. 87:3288-3299. http://dx.doi.org/10.2527/ jas.2008-1710.

Steele, M. A., C. Schiestel, O. AlZahal, L. Dionissopoulos, A. H. Laarman, J. C. Matthews, and B. W. McBride. 2015. The periparturient period is associated with structural and transcriptomic adaptations of rumen papillae in dairy cattle. J. Dairy Sci. http://dx.doi. org/10.3168/jds.2014-8640.

Stewart, G. 2011. The emerging physiological roles of the SLC14A family of urea transporters. Br. J. Pharmacol. 164:1780-1792. http://dx.doi.org/10.1111/j.1476-5381.2011.01377.x.

Sunny, N. E., S. L. Owens, R. L. Baldwin, S. W. El-Kadi, R. A. Kohn, and B. J. Bequette. 2007. Salvage of blood urea nitrogen in sheep is highly dependent on plasma urea concentration and the efficiency of capture within the digestive tract. J. Anim. Sci. 85:1006-1013. http://dx.doi.org/10.2527/jas.2006-548.

Tajima, K., R. I. Aminov, T. Nagamine, H. Matsui, M. Nakamura, and Y. Benno. 2001. Diet-dependent shifts in the bacterial population of the rumen revealed with real-time PCR. Appl. Environ. Microbiol. 67:2766-2774. http://dx.doi.org/10.1128/AEM.67.6.27662774.2001 .

Trevisi, E., M. Amadori, A. M. Bakudila, and G. Bertoni. 2009. Metabolic changes in dairy cows induced by oral, low-dose interferon-alpha treatment. J. Anim. Sci. 87:3020-3029. http://dx.doi. org/10.2527/jas.2008-1178.

Trevisi, E., M. Amadori, S. Cogrossi, E. Razzuoli, and G. Bertoni. 2012. Metabolic stress and inflammatory response in high-yielding, periparturient dairy cows. Res. Vet. Sci. 93:695-704. http://dx.doi. org/10.1016/j.rvsc.2011.11.008.

Trevisi, E., M. Amadori, F. Riva, G. Bertoni, and P. Bani. 2014. Evaluation of innate immune responses in bovine forestomachs. Res. Vet. Sci. 96:69-78. http://dx.doi.org/10.1016/j.rvsc.2013.11.011.

Ulluwishewa, D., R. C. Anderson, W. C. McNabb, P. J. Moughan, J. M. Wells, and N. C. Roy. 2011. Regulation of tight junction permeability by intestinal bacteria and dietary components. J. Nutr. 141:769-776. http://dx.doi.org/10.3945/jn.110.135657.

Um, S. H., D. D'Alessio, and G. Thomas. 2006. Nutrient overload, insulin resistance, and ribosomal protein S6 kinase 1, S6K1. Cell Metab. 3:393-402. http://dx.doi.org/10.1016/j.cmet.2006.05.003.

Wang, X., X. Li, C. Zhao, P. Hu, H. Chen, Z. Liu, G. Liu, and Z. Wang. 2012. Correlation between composition of the bacterial community and concentration of volatile fatty acids in the rumen during the transition period and ketosis in dairy cows. Appl. Environ. Microbiol. 78:2386-2392. http://dx.doi.org/10.1128/AEM.07545-11. 